\title{
Lidar Observations of the Swash Zone of a Low-Tide Terraced Tropical Beach under Variable Wave Conditions: The Nha Trang (Vietnam) COASTVAR Experiment
}

\author{
Luís Pedro Almeida ${ }^{1,2}, *\left(\mathbb{D}\right.$, Rafael Almar ${ }^{2}{ }^{\circ}$, Chris Blenkinsopp ${ }^{3}$, Nadia Senechal ${ }^{4}$, \\ Erwin Bergsma ${ }^{5}{ }^{(D}$, France Floc'h ${ }^{6}\left(\mathbb{D}\right.$, Charles Caulet $^{6}$, Melanie Biausque ${ }^{7}$, \\ Patrick Marchesiello ${ }^{2}$, , Philippe Grandjean ${ }^{8}$, Jerome Ammann ${ }^{6}$, Rachid Benshila ${ }^{2}$, \\ Duong Hai Thuan ${ }^{9}$, Paula Gomes da Silva ${ }^{10}{ }^{10}$ and Nguyen Trung Viet ${ }^{9}{ }^{(0)}$ \\ 1 Instituto de Oceanografia, Universidade Federal do Rio Grande (FURG), Rio Grande 96203-900, Brazil \\ 2 Laboratoire d'Etudes en Géophysique et Océanographie Spatiales (LEGOS), \\ Université de Toulouse/CNRS/CNES/IRD, 31400 Toulouse, France; rafael.almar@ird.fr (R.A.); \\ Patrick.Marchesiello@ird.fr (P.M.); rachid.benshila@legos.obs-mip.fr (R.B.) \\ 3 Department of Architecture and Civil Engineering, University of Bath, Bath BA2 7AY, UK; \\ c.blenkinsopp@bath.ac.uk \\ 4 UMR 5805 EPOC, CNRS-Université de Bordeaux, CS 50023-33615 Pessac, France; \\ nadia.senechal@u-bordeaux.fr \\ 5 Centre National d'Études Spatiales (CNES), 31400 Toulouse, France; erwin.bergsma@legos.obs-mip.fr \\ 6 Laboratoire Géosciences Océans-UMR 6538, CNRS-Université de Bretagne Occidentale, \\ F-29280 Plouzané, France; france.floch@univ-brest.fr (F.F.); charles.caulet@univ-brest.fr (C.C.); \\ jerome.ammann@univ-brest.fr (J.A.) \\ 7 School of Geography and Environmental Science, Ulster University, \\ Coleraine BT52 1SA, Northern Ireland, UK; m.biausque@ulster.ac.uk \\ 8 Laboratoire de Géologie de Lyon: Terre, Planètes, Environnement-UMR 5276, Université de Lyon, \\ F-69622 Villeurbanne, France; philippe.grandjean@univ-lyon1.fr \\ 9 Faculty of Civil Engineering, Thuyloi University, Hanoi 116705, Vietnam; \\ duonghaithuan@tlu.edu.vn (D.H.T.); nguyentrungviet@tlu.edu.vn (N.T.V.) \\ 10 Coastal Oceanography Laboratory, Federal University of Santa Catarina, Florianópolis 88040-900, Brazil; \\ silvapgomes@gmail.com \\ * Correspondence: lpalmeida@furg.br
}

Received: 12 March 2020; Accepted: 23 April 2020; Published: 26 April 2020

check for updates

\begin{abstract}
A field experiment was conducted at a tropical microtidal intermediate sandy beach with a low tide terrace (Nha Trang, Vietnam) to investigate the short-term swash-zone hydrodynamics and morphodynamics under variable wave conditions. Continuous 2D Lidar scanner observations of wave height at the lower foreshore, subsequent run-up and swash-induced topographic changes were obtained. These data were complemented by detailed real-time kinematic GPS topographic surveys. Variable wave and tide conditions were experienced during the field experiment with relatively large swell waves (offshore significant wave height, $H_{S}=0.9 \mathrm{~m}$ to $1.3 \mathrm{~m}$; peak wave period, $T_{p}=8$ to $12 \mathrm{~s}$ ) concomitant with spring tides at the beginning of the period, followed by mild wind waves (offshore $H_{s}$ under $0.5 \mathrm{~m}$ and $T_{p} 5 \mathrm{~s}$ ) and neap tides. This resulted in the following morphological sequence: berm erosion followed by rapid neap berm reformation and beach recovery within a few days. New insights into the link between intra-tidal swash dynamics and daily beach profile evolution were found using the Lidar dataset. While waves directly cause morphology changes on a wave-by-wave basis, tidal levels were found to be a key factor in determining the morphological wave-effect (accretive or erosive) due to modulated interaction between surf and swash hydro-morphodynamics.
\end{abstract}


Keywords: swash zone; low-tide-terrace; Lidar; tide; Nha Trang—Vietnam

\section{Highlights}

- Nine-day detailed swash hydro-morphodynamic measurements of wave induced erosion and recovery on a tropical beach (Nha Trang, Vietnam) with a Lidar.

- The wave height measured on the lower foreshore and active slope are key parameters to predict vertical run-up on this type of intermediate beach.

- Tide induces a strong modulation of wave action and drives large intra- and daily changes on the swash zone.

\section{Introduction}

Beaches continuously adapt to wave forcing at multiple temporal [1-3] and spatial scales [4] and the morphological changes commonly observed in these environments are particularly related to the hydrodynamics of the swash zone. Swash flows are composed of two distinct phases, an upslope, landward directed flow (uprush) and a downslope, seaward directed flow (backwash). Although there is a continuum of energy in swash spectra, they are commonly divided into short wave ( $\mathrm{f}>0.05 \mathrm{~Hz}$ ) and long wave, or infragravity, frequency bands $(\mathrm{f}<0.05 \mathrm{~Hz})$. The short wave band is normally more energetic in bore-dominated, steeper intermediate and reflective beaches [2], while swash variance in the infragravity band is typically observed on low gradient beaches [3]. Sandy beaches with a steep upper slope and flat low-tide terrace (LTT) represent one of four types of intermediate beaches [4] where the two distinct hydrodynamic regimes (reflective and dissipative) can be observed at different stages of the tide $[5,6]$.

The wave breaker type affects the processes in the swash zone. For example, previous work [7] has suggested that the breaker type directly influences sediment transport, since the amount of turbulence that reaches the sea bed leading to the suspension of sediment depends on the nature of breaking (e.g., plunging breaker vortices mobilize larger amounts of sediment than spilling breakers [8]). The turbulence generated by the bore collapse is advected into the swash-zone during the uprush [9], leading to a high concentration of suspended sediment. Subsequently, during the backwash, friction against the bed becomes the main source of turbulence [10]. This is enhanced in the lower swash region by the formation of backwash bores [11] and the hydraulic jump originating from the interaction between consecutive swashes [12]. The slope of the swash-zone also plays a significant role on swash-zone processes. The steeper the beach face, the more upslope transport is inhibited and more downslope transport is enhanced. The differences in forces that act during uprush and backwash lead to an asymmetry in swash velocity time-series $[13,14]$. If the incident wave conditions are constant, it becomes increasingly difficult to move sediment upslope on a steepening and accreting beach face and the beach slope approaches an equilibrium value. Similarly, on a flattening and eroding beach face, the slope contribution to the offshore sediment transport will progressively decrease, and the beach profile will eventually approach equilibrium [15]. On a steep LTT, however, tide-induced changes in the breaker type and swash-zone slope are expected to strongly influence swash processes, in particular the swash asymmetry [14]. Tidal modulation of breaker type (e.g., plunging breakers at high tide and spilling breakers at low tide) are known to occur on this type of beach [5,6]; however, the extent to which tidal variation affects the swash-zone hydrodynamics and, hence, the morphological response is still unclear [7]. Furthermore, although these theoretical concepts provide a basis for understanding the swash dynamics on this type of intermediate beach, the details of the process are highly complex, and limited field observations exist for validation.

Most previous research on steep beaches with an LTT has been performed on mixed sand-gravel beaches (MSG), where typically the upper-beach face is composed of gravel and the terrace of sand $[5,16-18]$. Similarities between MSG beaches and pure sandy beaches is mostly limited to the 
terrace where hydrodynamics and sediment transport mechanisms are analogous. The most landward region of the inner surf and swash zone-dynamics are controlled by factors specific to MSG beaches, including the role of the beach step [19], enhanced infiltration/exfiltration [20], the dominance of bedload transport, and strong wave reflection.

Significant recent developments in techniques for remotely sensing coastal processes have made available a number of solutions, including ultrasonic altimeters, photographic techniques and Lidar, that allow simultaneous observations of water motions and bed changes in the swash-zone [21-25]. Of these technologies, Lidar has significant advantages as it provides non-intrusive, direct measurements of both water and bed surface elevation at high spatial and temporal resolution, and has minimal logistical requirements for deployment. Lidar scanners can be deployed on a frame above the swash-zone or from coastal structures such as piers to overlook the surf and swash zones [26]. Over recent years, processes in the surf and swash zones have been observed using Lidar, including more detail and with an accuracy comparable to that of other commonly used techniques [24,27-32].

In this work, we present a detailed analysis of a dataset obtained during a field experiment. Hydrodynamics and morphology measured using Lidar during a nine-day field experiment are used to assess swash asymmetry and the role of wave and tidal variability on swash-zone morphology at an intermediate low-tide terrace beach.

\section{Methods}

\subsection{Study Area}

As part of the COASTVAR project (multi-scale and multi-method study of coastal variability in the Gulf of Guinea and Vietnam), a field experiment was undertaken between 26th November and 4th December 2015 at Nha Trang Beach, a sandy beach located in a semi-enclosed bay in southeast Vietnam (Figure 1). The bay is approximately $6 \mathrm{~km}$ long, has an overall NE-SW coastal orientation and is partially protected from waves in the South China Sea (SCS) by a group of islands (Figure 1). The mean sediment size varies considerably within the bay, with coarse sand in the north $\left(D_{50}=0.9 \mathrm{~mm}\right)$, reducing to medium to coarse in the south $\left(D_{50}=0.4 \mathrm{~mm}\right)$. The experiment described here was conducted in the northern part of the bay where the beach profile is characterized by a steep upper foreshore (slope $\sim$ 1:10) and a narrow, flat (slope $\sim$ 1:100) and uniform LTT, approximately $40 \mathrm{~m}$ wide (Figure 2, [33,34]). The wave climate in this region is strongly influenced by the two monsoon seasons, the northeast (NM) and southwest (SM) monsoons. The NM is characterized by moderate winds (between 8 and $12 \mathrm{~m} / \mathrm{s}$ ) and energetic waves, typically occurring during the wet season (November to January), while the SM is characterized by mild winds and waves, between June and September [34-36]. In addition to the monsoon seasons, tropical cyclones, also known as typhoons, can produce very energetic waves in the SCS, resulting in sporadic but significant erosion and inundation hazards [37-39]. Nha Trang Beach is characterized by a mixed tide (combination of daily and semi-daily tide components) with microtidal amplitude (maximum amplitude of $1.5 \mathrm{~m}$ ). 


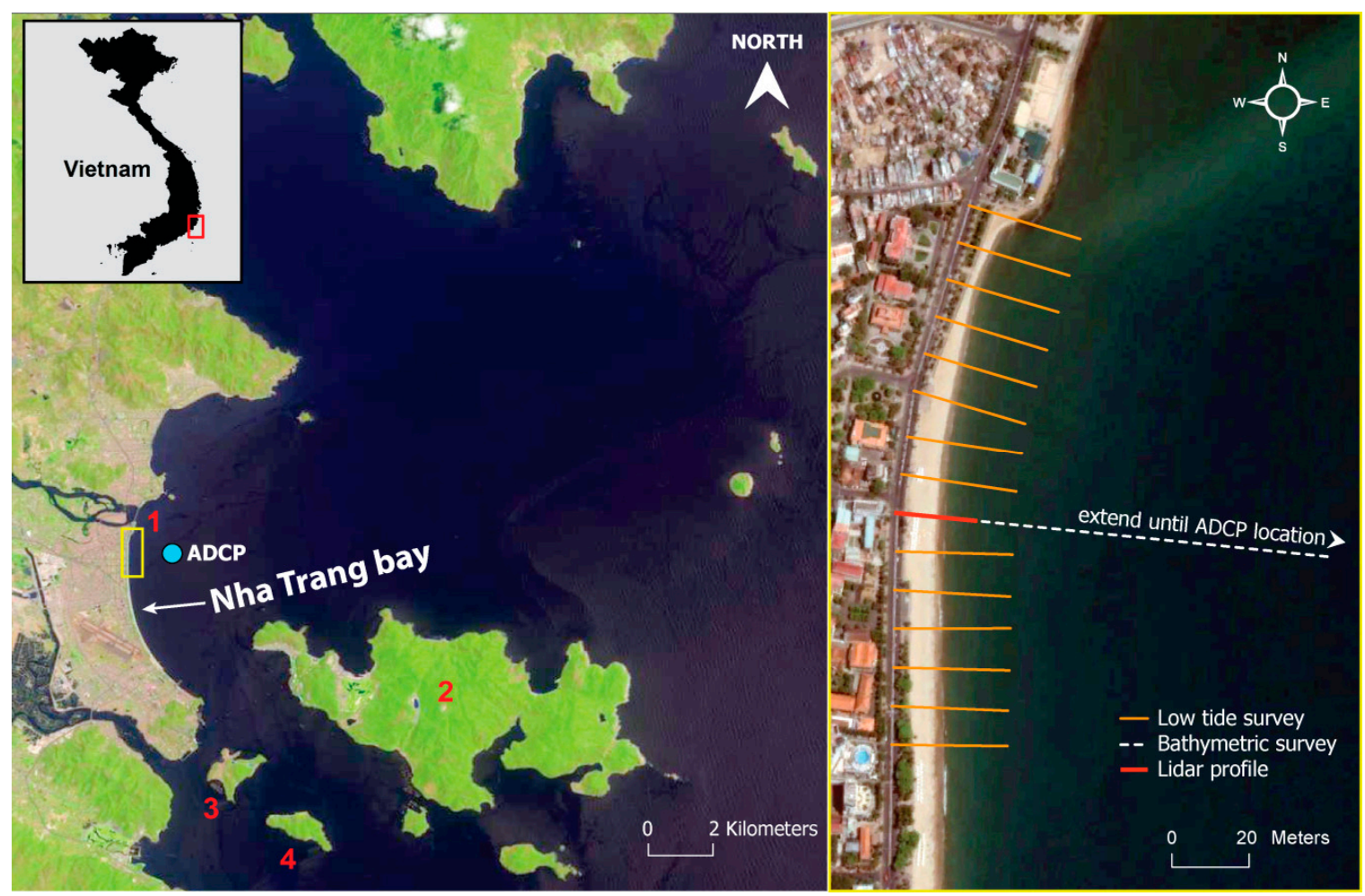

Figure 1. Left: Location of Nha Trang bay and some important local features including: 1-Cai estuary; 2-Hon Tre island; 3-Hon Mieu island; 4-Hon Tam island. The yellow box indicates the section of the beach selected for this experiment (zoomed in the right panel). Right: Aerial photograph of the study site in which orange lines indicate the 15 cross-shore transects where topographic surveys were performed every low tide; in red is the profile where instruments were installed (right panel).

\subsection{Experimental Set-up}

A range of in-situ and remote sensing instruments were deployed along a cross-shore transect of the beach from the berm crest to depth offshore of $15 \mathrm{~m}$ (Figure 2). An acoustic Doppler current profiler (ADCP) was moored at $15 \mathrm{~m}$ depth (Figure 1) and provided a complete characterization of the offshore wave conditions during the experiment. A 2D Lidar was installed on a tower located at the top of the berm with an elevation of $3.5 \mathrm{~m}$ to measure inner surf and swash-zone hydrodynamics (free-surface elevation and instantaneous shoreline position, see [31,40]), and morphological evolution. Topographic surveys were performed every low tide using a real-time kinematic GPS system (RTK-GPS) in continuous survey mode along 15 cross-shore transects spaced by $10 \mathrm{~m}$ (Figure 1). The results described in the present work are based on the data obtained from the ADCP, Lidar, and topographic survey data (only the topographic data from 3 of the 15 transects was used in this manuscript—see Figure 2). 

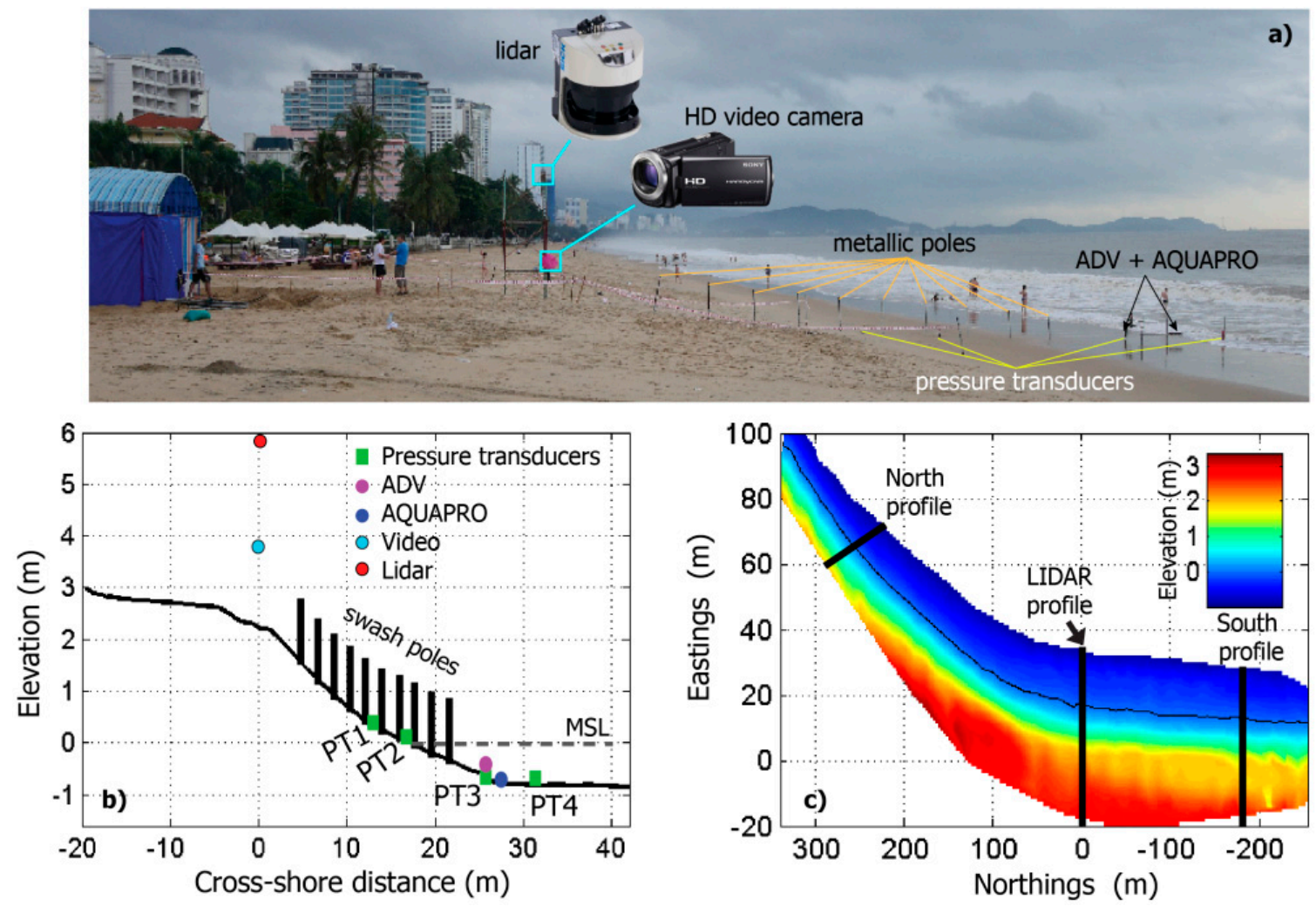

Figure 2. Photograph showing the arrangement of all instruments along a cross-section of the beach (a); beach profile with instrument location and mean sea level (MSL) indication during this experiment (b); contour map of the study site topography with LIDAR profile location and two additional profiles used in this analysis (c).

\subsection{Two-Dimensional Lidar}

The Lidar deployed at the berm tower was a medium-range SICK LMS511 2D laser scanner (maximum range $80 \mathrm{~m}$, and $30 \mathrm{~m}$ at $10 \%$ remission). The Lidar emits pulsed infrared laser beams $(\lambda=905 \mathrm{~nm})$ that are deflected onto an internal mirror rotating over a 190 degree field of view. The scanner head rotates at $25 \mathrm{~Hz}$ leading to an angular resolution of 0.1667 degrees and the target distance is calculated using the time of flight technique. With this angular resolution, the instrument provided a spatial resolution ranging from $0.01 \mathrm{~m}$ at nadir to $0.4 \mathrm{~m}$ at the most distant valid observation point offshore (Figure 3). This spatial resolution allowed complete coverage of the swash-zone and captured wave conditions at the base of the foreshore throughout the experiment.

The raw Lidar data captures both beach topography as well as the water surface, without any distinction between the two (Figure 3b). To separate the topography from the water at each cross-shore position, and over time, a moving-average time window variance filter was applied to all measurements, following the approach described in [29]. After initial data processing, the Lidar data were separated into two distinct time series: (1) beach topography (Figure 3d) and (2) swash (including water depth and instantaneous shoreline evolution-Figure 3c). 

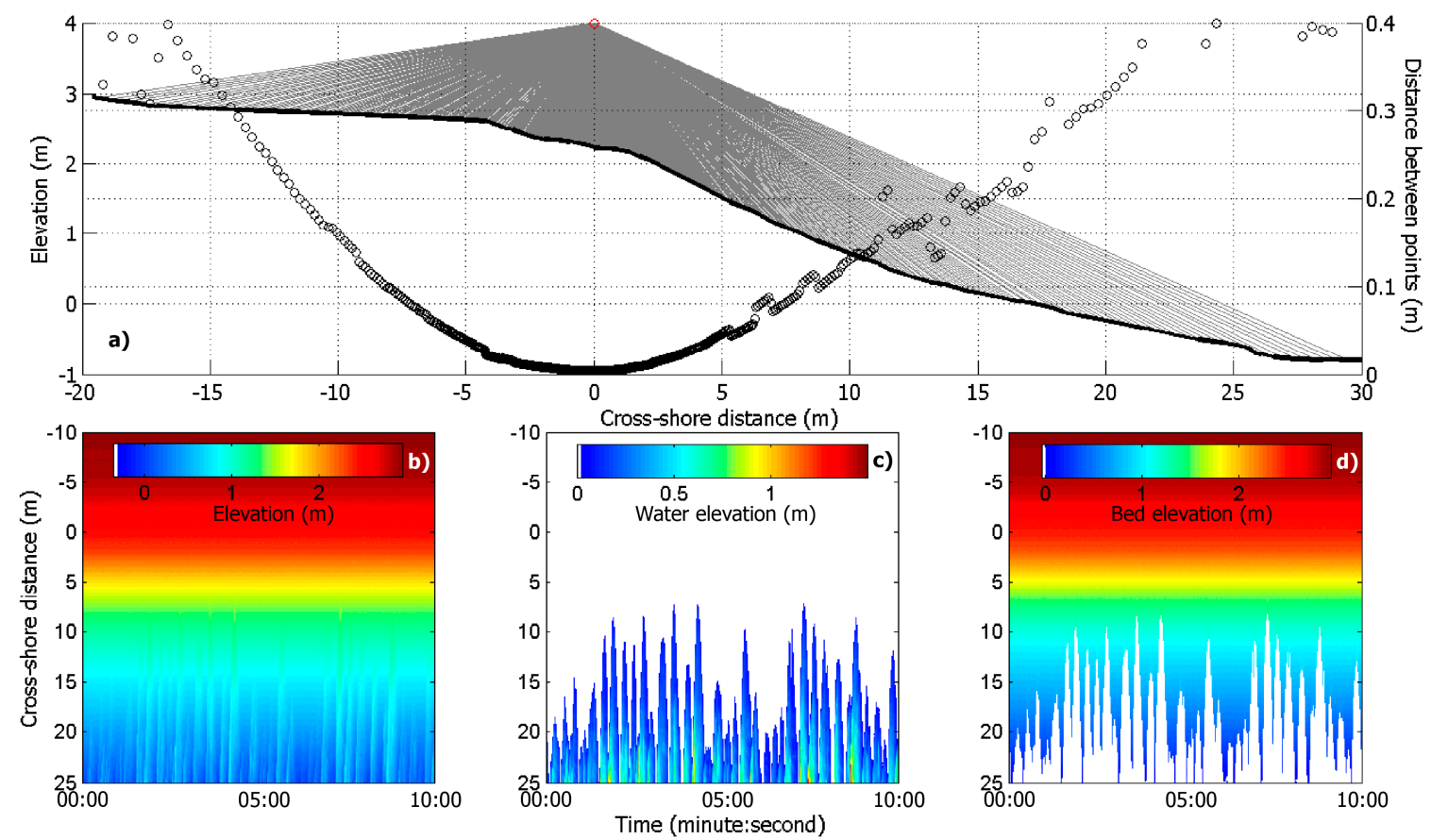

Figure 3. (a) Beach profile the Lidar position shown as a red circle and theoretical projection of the different laser beams on the topography of the beach. The distance between observations (black spots) is calculated as the horizontal distance between consecutive measurements of the laser beams (a); the lower panels show an example of raw Lidar time series (b) and post-processing products: water elevation (c) and bed altitude (d) time series.

As the grazing angle between the Lidar and the target decreases, the energy scattered back to the instrument reduces and the variability of the signal increases [29]. This can be important when tracking the water surface. While bore fronts can still be captured due to their more normal orientated surface (relative to the Lidar) and the active foam that they produce, laser beam reflections from a more horizontal (non-foamy) surface are weaker or can be lost. As a result, the number of data gaps or spikes due to erratic returns increases seaward with the distance to the Lidar. For this reason, Lidar observations used here (both water levels and bed elevations) were truncated at a cross-shore distance of $25 \mathrm{~m}$ relative to the Lidar.

\section{Results}

\subsection{Offshore Wave Forcing}

Wave and tidal conditions during this experiment varied considerably (Figure 4a). The first four days of the experiment (27-30 November 2015) were characterized by energetic swells (narrow-banded energy band around $0.1 \mathrm{~Hz}$ - present in the wave spectra-Figure $4 \mathrm{~d}$ ) with offshore waves recorded by the moored ADCP having a significant wave height $\left(\mathrm{H}_{\mathrm{s}}\right)$ between 0.9 and $1.3 \mathrm{~m}$, and wave peak period $\left(T_{p}\right)$ between 8 and $12 \mathrm{~s}$, and spring tides ( $1.2 \mathrm{~m}$ amplitude). The following four days of the experiment were characterized by mild wind waves, with $\mathrm{H}_{\mathrm{s}}$ under $1 \mathrm{~m}, \mathrm{~T}_{\mathrm{p}}$ between five and eight seconds and a gradual reduction in tidal amplitude $(<1 \mathrm{~m})$. It is important to note that the mixed nature of the tide (double high tide peak) was more pronounced during spring tide conditions and gradually weakened under neap tides (Figure 4a). 

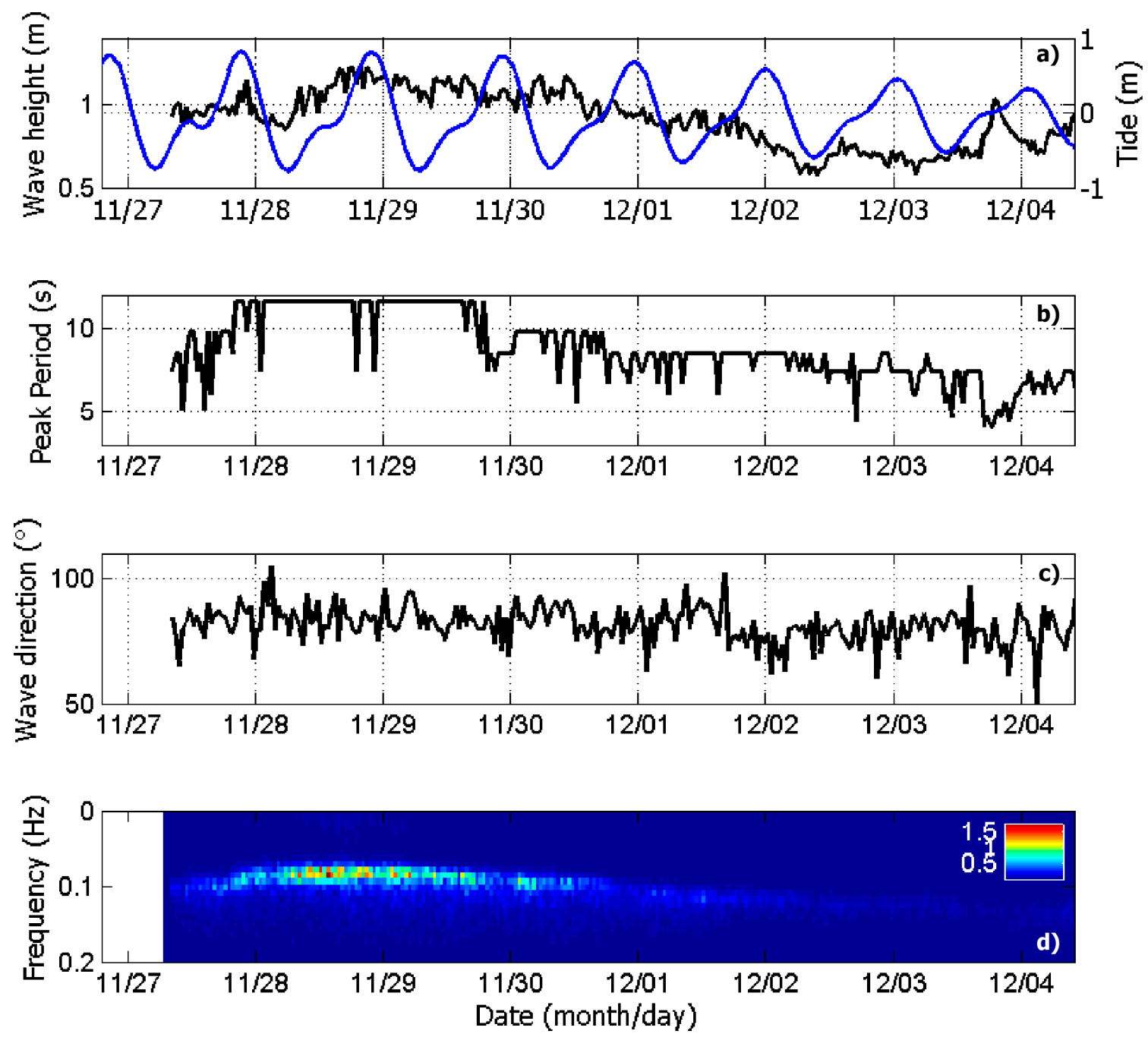

Figure 4. Measurements of tides (blue line) and significant wave height obtained from the ADCP moored off the study site: (a) peak wave period, (b) mean wave direction, and (c) normalized wave spectrum (d).

\subsection{Wave Characteristics and Run-up Observed from the Lidar}

The wave characteristics at the base of the foreshore $(x=25 \mathrm{~m}$, see Figure 2$)$ and the vertical run-up time-series obtained from the Lidar observations were separated into 15-minute bursts, with the assumption of tidal stationarity within each burst. For each burst, spectral energy density and significant wave heights $\left(H_{s, \text { LIDAR }}\right)$ were computed from the Lidar data at the same cross-shore location. In addition, the Iribarren number [41] was calculated as $\xi=\tan \beta / \sqrt{\left(H_{s} / L_{0}\right)}$, where $L_{0}$ is the offshore wavelength measured at the ADCP and $\tan \beta$ is the active foreshore slope extracted from the Lidar dataset (here, $\tan \beta$ is defined as the slope between the maximum run-up elevation and the minimum elevation of the run-down). The significant vertical run-up height $\left(R_{s}\right)$ was calculated as four times the standard deviation of the shoreline elevation time series $(R)$ within each 15-minute burst.

The time series of the $\mathrm{H}_{\text {SLIDAR }}$ show a general trend similar to that of the offshore $\mathrm{H}_{\mathrm{s}}$, with initially larger waves up to $\mathrm{H}_{\text {SLIDAR }}=1.6 \mathrm{~m}$ that gradually decreased as the experiment progressed (Figure 5). The significant wave height measured at the base of the foreshore displayed a clear tidal dependence (Figure 5) indicating depth-control on surf zone wave heights as observed at other intermediate beach sites [42] and highlighting the role of the LTT on incident wave energy dissipation in the surf zone (Figure 5). The significant run-up height and periods also show a strong tidal modulation, suggesting that mean water levels are key factors controlling swash zone hydrodynamics at Nha Trang Beach. 
Calculations of wave power energy spectral density indicate that tidal modulation of the $\mathrm{H}_{\text {sLIDAR }}$ and $R_{s}$ affects not only the height of the waves but also the wave period through the distribution of energy between the infragravity and gravity frequency bands (Figure 5c). During low tide, lower water levels favor wave breaking on the gently sloping LTT, creating very dissipative conditions, and the LTT acts as a low-pass filter to the swash-zone [43], dissipating a large part of the wave energy in the short wave band (f between 0.05 and $0.3 \mathrm{~Hz}$ ). This results in a dominance of infragravity waves $(f<0.05 \mathrm{~Hz})$ that do not fully dissipate in the surf-zone. At high tide, the water level in the LTT is greater and the terrace becomes less efficient at dissipating the energy of incident short waves. A clear indication of this modification in the hydrodynamic regime is given by the ratio between offshore significant wave

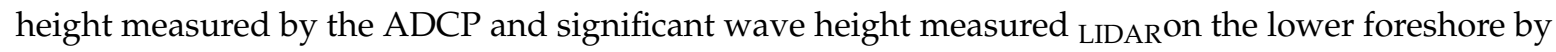
the Lidar $\left(\mathrm{H}_{\mathrm{s}} / \mathrm{H}_{\mathrm{sLIDAR}} ;\right.$ Figure 6). During high tide conditions, this ratio is close to 1 ( $\mathrm{H}_{\mathrm{sLIDAR}}$ is similar to $\mathrm{H}_{\mathrm{s}}$ ) while, during low tide conditions, $\mathrm{H}_{\text {sLIDAR }}$ is up to 3.5 times larger than $\mathrm{H}_{\mathrm{s}}$.
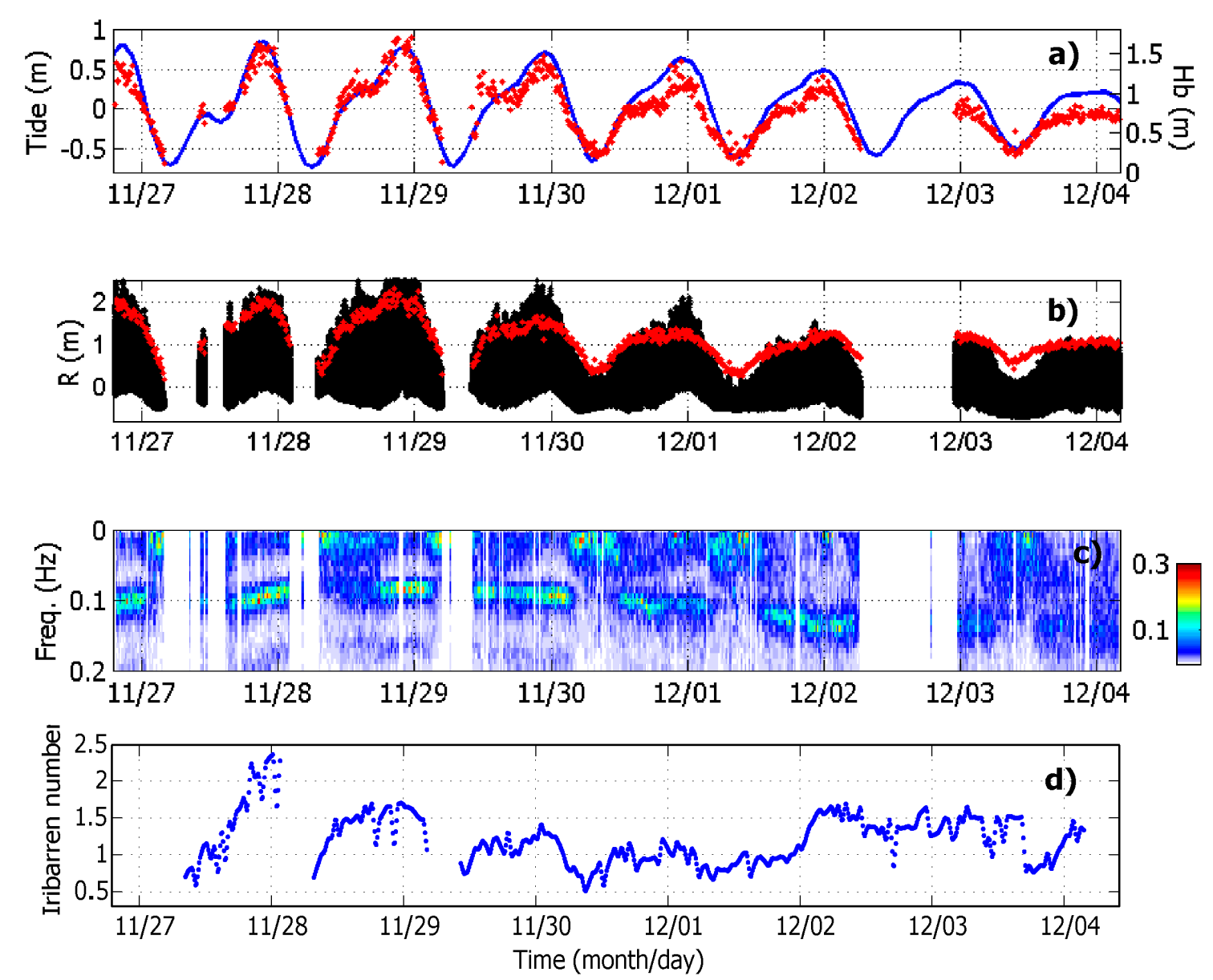

Figure 5. (a) Time series of (a) $H_{S L I D A R}$ measured on the lower foreshore using the Lidar (red dots) with the overlap of measured tide (blue line); (b) raw vertical run-up observations (black dots) and significant vertical run-up (red dots); (c) normalized wave spectra measured on the lower foreshore, and; (d) Iribarren number (blue dots). 


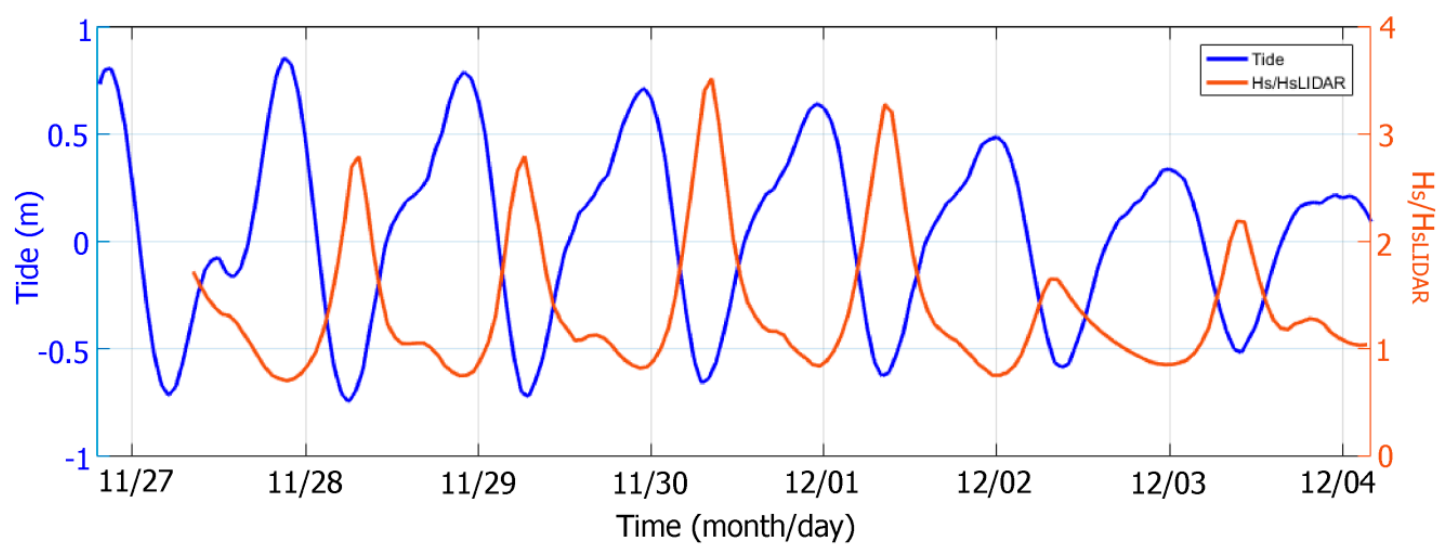

Figure 6. Timeseries of the ratio between offshore significant wave height $\left(\mathrm{H}_{\mathrm{S}}\right)$ and significant wave height measured on the lower foreshore by the Lidar $\left(\mathrm{H}_{\mathrm{SLIDAR}}\right)$ is shown in orange and the tidal elevation is in blue.

To evaluate the effect of tide on the role of the beach profile and wave characteristics on run-up, data were grouped according to the tide level, following the approach proposed by [44]. Groups were defined as low-, mid-, and high-tide. The boundaries of these groups were arbitrarily defined as $1 / 3$ (low to mid) and 2/3 (mid to high) of the tidal range observed at Nha Trang beach. The significant run-up elevation, $R_{s}$ was compared to various parameters commonly related to the run-up $[44,45]$. Figure 7 shows three scatter plots of the significant vertical run-up $\left(R_{s}\right)$ as a function of offshore wave characteristics $\left(\left(\mathrm{H}_{\mathrm{s}} \mathrm{L}_{\mathrm{o}}\right)^{0.5}\right), \tan \beta(\mathrm{HsLo})^{0.5}$ and $\tan \beta\left(\mathrm{H}_{\mathrm{SLIDAR}} \mathrm{Lo}\right)^{0.5}$, where $\tan \beta$ is the foreshore slope measured by the Lidar. The results show that the vertical run-up at Nha Trang beach cannot be scaled by offshore wave conditions solely, as very low determination coefficients $\left(\mathrm{r}^{2}=0.43\right)$ were obtained for the relationship between $\mathrm{R}_{\mathrm{s}}$ and $\left(\mathrm{H}_{\mathrm{s}} \mathrm{L}_{\mathrm{o}}\right)^{0.5}$ (Figure 7a). The ratio $\tan \beta(\mathrm{HsLo})^{0.5}$ was able to explain $78 \%$ of the variability observed in the vertical run-up observations; nevertheless, when $\mathrm{H}_{\mathrm{s}}$ was replaced by the $\mathrm{H}_{\mathrm{sLIDAR}}$, the ratio was able to explain $88 \%$ of the variability (Figure 7 ).
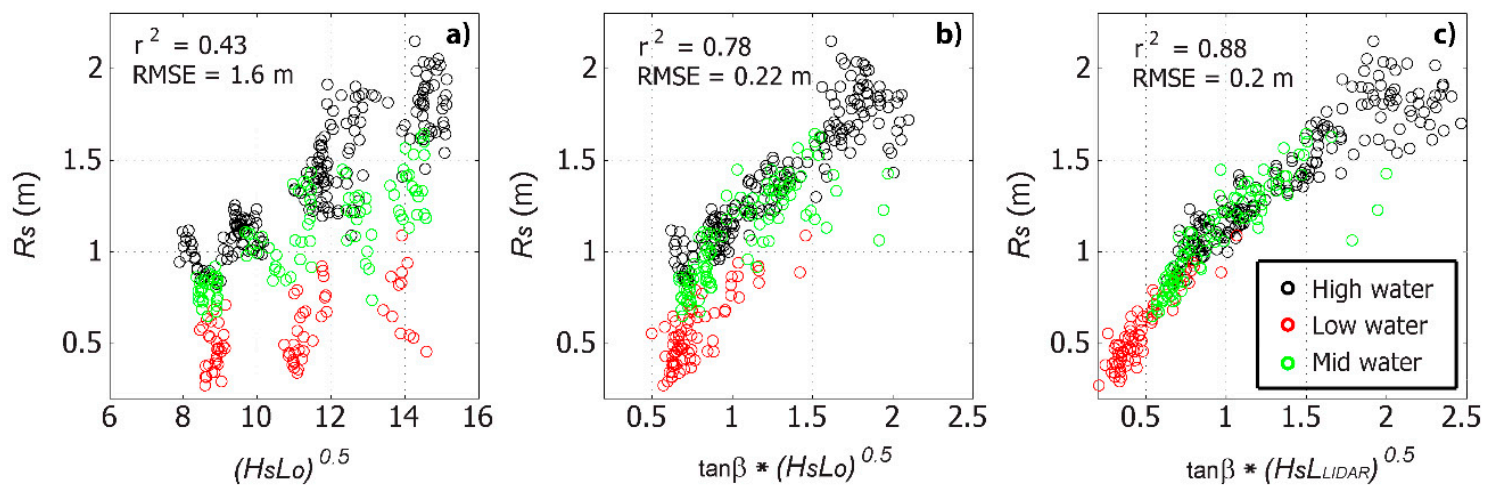

Figure 7. Scatter plots of the significant vertical run-up $\left(\mathrm{R}_{\mathrm{S}}\right)$ as a function of $\left(\mathrm{H}_{\mathrm{S}} \mathrm{L}_{\mathrm{O}}\right)^{0.5}(\mathbf{a}), \tan \beta\left(\mathrm{H}_{\mathrm{S}} \mathrm{L}_{\mathrm{O}}\right)^{0.5}$ (b), and $\tan \beta\left(\mathrm{H}_{\text {SLIDAR }} \mathrm{L}_{\mathrm{o}}\right)^{0.5}$ (c). The red, black and green colors are related to the low, high and mid tide levels respectively.

Table 1 shows that overall, run-up estimations are better during high-tide for this intermediate beach, which is likely to be due to the reduced influence of the LTT on surf-zone wave transformation. As a result, high correlation coefficient values were obtained for all the tested parameters. Similar results were also observed at other intermediate beaches by [46,47]. Table 1 also indicates that $H_{S L I D A R}$ has a particular importance for run-up predictions during low-tide conditions, when offshore wave height measurements are significantly different from the wave heights measured at the base of the foreshore (Table 1). 
Table 1. Statistical results of the linear regression between $R_{S}$ and three different dimensional versions of an Iribarren-based relationship.

\begin{tabular}{ccccccc}
\hline \multirow{2}{*}{ Parameter } & \multicolumn{2}{c}{ High-Tide } & \multicolumn{2}{c}{ Mid-Tide } & \multicolumn{2}{c}{ Low-Tide } \\
\cline { 2 - 7 } & $\boldsymbol{r}^{\mathbf{2}}$ & RMSE $(\boldsymbol{m})$ & $\boldsymbol{r}^{\mathbf{2}}$ & RMSE $(\boldsymbol{m})$ & $\boldsymbol{r}^{\mathbf{2}}$ & RMSE $(\boldsymbol{m})$ \\
\hline$\left(H_{S} L_{0}\right)^{0.5}$ & 0.68 & 1.01 & 0.35 & 1.3 & 0.3 & 1.5 \\
\hline $\tan \beta\left(H_{S} L_{O}\right)^{0.5}$ & 0.85 & 0.2 & 0.64 & 0.19 & 0.65 & 0.13 \\
\hline $\tan \beta\left(H_{S L I D A R} L_{O}\right)^{0.5}$ & 0.88 & 0.2 & 0.77 & 0.16 & 0.83 & 0.07 \\
\hline
\end{tabular}

\subsection{Daily Morphological Evolution}

The daily morphological evolution of the study site was assessed at three different locations (Lidar profile and transects to the north and south of the Lidar profile-see Figure 2) through low tide beach surveys performed using RTK-GPS (Figure 8). Initial surveys (measured on the 27/11) showed that the Lidar profile was similar to the south profile, with both showing a berm and a concave beach face shape. On the north profile, the berm was absent, the top of the profile was truncated at the seawall and the beach face was characterized by a steep slope with a slightly convex shape (Figure 8 ). It is important to note that the LIDAR and the south profiles were located on the straight section of Nha Trang bay, while the north profile was located on the curvilinear end of the bay. This is important since the morphological response observed during the experiment at the north profile was distinct from the LIDAR and south profiles. While at the north profile, the lower foreshore was progressively eroded and the top of the profile slightly accreted, and at the LIDAR and south profile, the initial berm erosion was followed by the development of a neap-berm. The erosion of the berm occurred on the 28/11, when spring tides together with energetic waves were present. Part of the eroded sand was deposited landward over the berm crest due to the overtopping processes, with the remainder being transported onto the LTT (Figure 8). The berm formation phase started on 29/11 and ceased on 03/12, when no further growth was observed. This phase was characterized by a decrease in the tidal range and lowering offshore wave heights. As a result, reduced wave run-up was no longer able to reach the pre-existing berm crest leading to an accumulation of sediment lower on the foreshore (Figure 8). While these cross-shore sediment exchanges were observed at the LIDAR and south profile, in the north a persistent erosion of the lower foreshore did not result in a proportional accumulation on the top of the profile. Since no evident along-shore gradient in sediment transport and morphological changes were noticed during the present experiment, it is suggested that the eroded sediment was likely transported offshore, beyond the limit of the surveys.

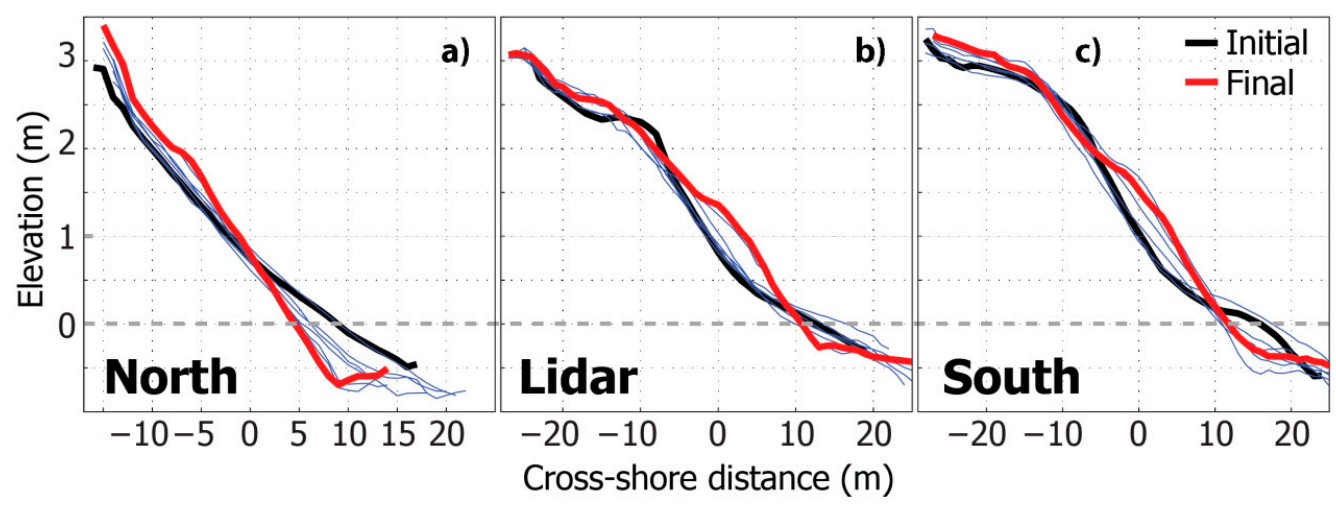

Figure 8. Daily low tide cross-shore beach profiles measured at (a) the North, (b) LIDAR and (c) South transects, the locations of which are shown in Figure 2. 


\subsection{Intra-Tidal Morphological Evolution}

The morphological evolution of the swash-zone was assessed using high-frequency observations obtained using the Lidar. Time-averaged (over 15-min segments) beach profiles were used to compute cumulative vertical changes (Figure 9). Inspection of Figure 9 shows the significant intra-tidal morphological changes that occurred within the swash-zone: berm erosion followed by the development of a neap-berm by the end of the experiment.
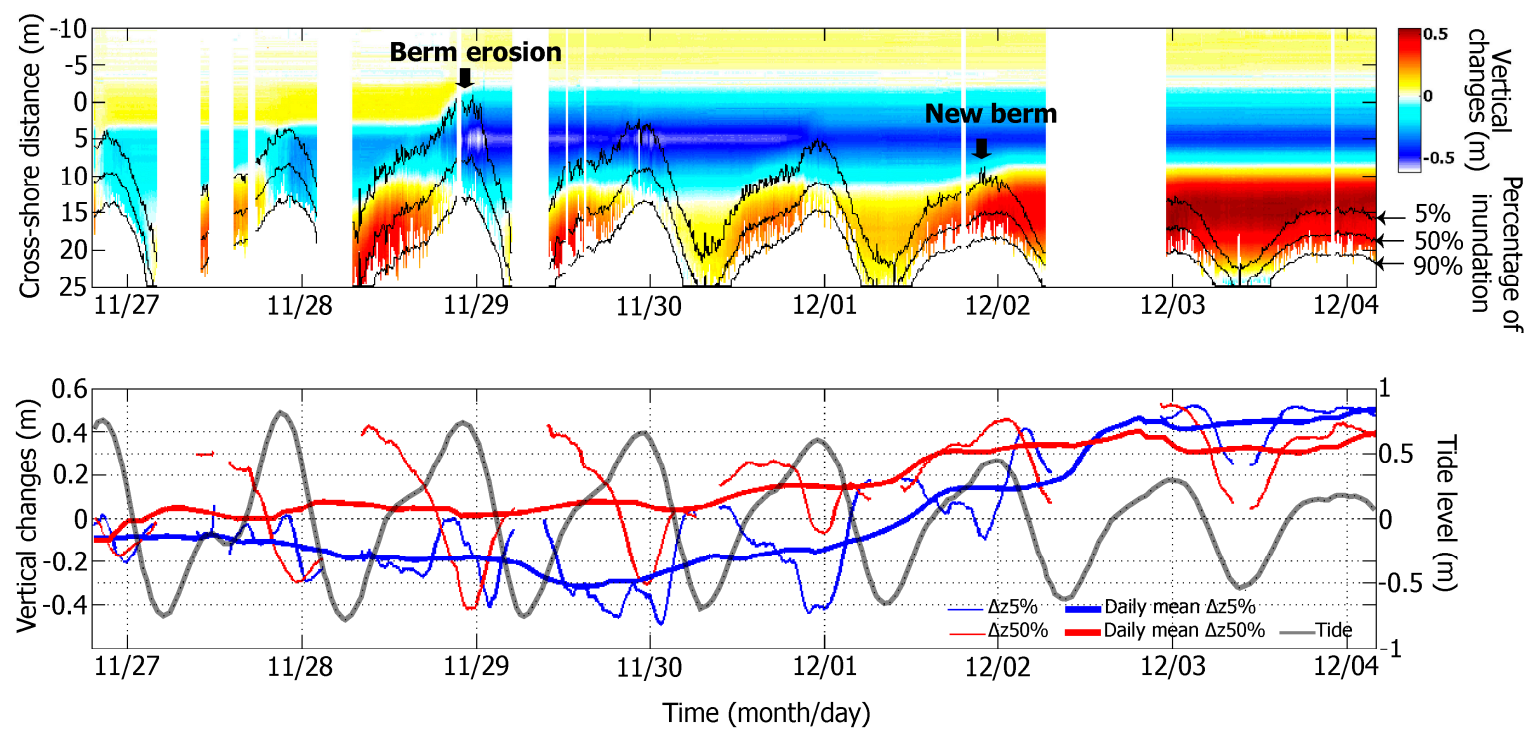

Figure 9. Beach response measured using the Lidar, with the top panel showing the cumulative vertical changes overlain by the $5 \%, 50 \%$ and $90 \%$ of swash inundation lines (percentage that specific swash location is covered by water during a 10 min segments); red colors indicate accretion while blue colors indicate erosion. The bottom panel presents the cumulative vertical bed elevation changes observed on the $5 \%$ and $50 \%$ inundation lines $\left(\Delta_{\mathrm{z} 5 \%}\right.$ and $\Delta_{\mathrm{z} 50 \%}$ respectively), together with the daily-mean values. The tidal elevation is indicated in grey.

Intra-tidal cycles of accretion and erosion were captured by the Lidar between 27/11 and 01/12, with the largest amplitude of changes around the mid-swash-zone location ( $\Delta_{\mathrm{z} 50 \%}$ in Figure 9$)$. During these cycles, an accretion phase was observed from the low to mid tide stage of the rising tide, followed by an erosive period from the mid to high-tide and falling tide stages (Figure 9). The accretion phase led the formation of sand deposits that reach up to $0.5 \mathrm{~m}$ and were completely remobilized on the subsequent falling tide, resulting in minor (close to zero) net of changes over the tidal cycle. As a result, the daily-mean cumulative vertical changes observed in the mid-swash zone are close to zero. A distinct pattern was observed in the upper swash-zone (5\% of inundation region), where negative net change was observed until 29/11; however, positive changes were observed after this. These results indicate that the net vertical changes observed in the upper swash-zone were directly related to modifications in the offshore wave conditions, which were characterized by relatively large, long period waves during the early part of the experiment followed by smaller, shorter period waves (see Figure $4 \mathrm{~d}$ ). In the mid swash, this relationship is not as clear.

\subsection{Morphological Evolution and Hydrodynamic Forcing}

The swash zone morphological evolution depends on multiple factors that act simultaneously, thus, including slope, incident wave height or run-up characteristics. A multiple linear regression (Equation (1)) was used to investigate the role of four forcing parameters on the cumulative vertical changes observed in the mid swash-zone (50\% inundation, $\Delta_{\mathrm{z} 50 \%}$ ). 


$$
Y=C_{0}+\sum_{1}^{n} C_{k} Z_{k}+\varepsilon
$$

where $Y$ is the prediction, $Z$ the predictor variable, $n$ is the number of hourly observations, $C_{0}$ and $C_{k}$ are the non-standardized regression coefficients and $\varepsilon$ is the residual term. The relative contribution (as a percentage) of each forcing parameter was estimated from the ratio of individual variance to the total following Equation (2):

$$
P(Z)=100 \sqrt{\frac{S_{k}}{S_{y}}(k=1,2,3,4)}
$$

where $S_{k}$ is the variance of $C_{k} Z_{k}$ and $S_{y}$ is defined as the sum of variances of all causative components to ensure a total of $100 \%$. The causative variables used in the multiple linear regression include incident wave height at the base of the foreshore $\left(\mathrm{H}_{\text {sLIDAR }}\right)$, the swash excursions variability, represented by the standard deviation of the vertical run-up $\left(\sigma \mathrm{R}_{\mathrm{z}}\right)$, and two parameters that relate the foreshore slope condition to the concomitant vertical run-up spectral bands (incident and infragravity, expressed by $\left(\tan \beta . R_{\text {incident }}\right)^{0.5}$ and $\left(\tan \beta . R_{\text {incident }}\right)^{0.5}$ respectively). The predictions based on the computed multiple linear regression was able to explain $78 \%$ of the variability in the $\Delta_{\mathrm{z} 50 \%}$ observations (Figure 10), including the intra-tidal cycles of accretion/erosion. Results show that $\left(\tan \beta R_{\text {infra }}\right)^{0.5}$ was the parameter with the largest contribution $(53 \%)$ followed by $\left(\tan \beta R_{\text {incid }}\right)^{0.5}(38 \%)$, with a minor contribution from $\mathrm{H}_{\mathrm{SLIDAR}}$ and $\sigma \mathrm{R}_{\mathrm{z}}$.
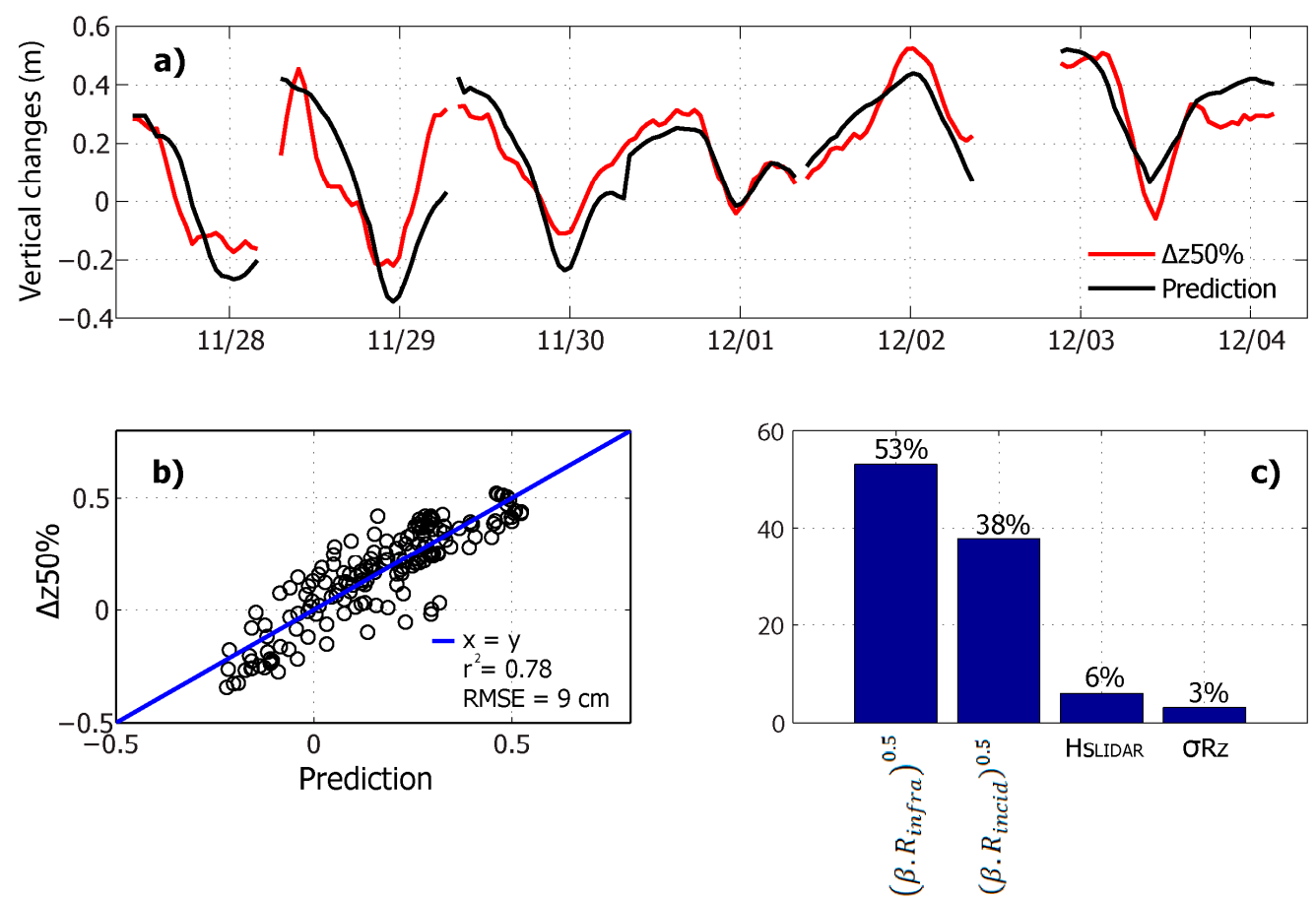

Figure 10. (a) Predictions of the multiple linear regression model (black line) compared with the cumulative vertical changes in the mid swash zone $\left(\Delta_{\mathrm{z} 50 \%}\right.$, red line) observed during the field experiment. (b) Scatter diagram showing the correlation between the multiple linear regression model and $\Delta_{\mathrm{z} 50 \%}$ observations. The coefficient of correlation $\left(\mathrm{r}^{2}\right)$ obtained for this linear regression was 0.78 . (c) Individual contributions of the forcing parameters used in the multiple linear regression expressed as a percentage.

\section{Discussion}

\subsection{Tidal Modulation of Waves and Run-Up Heights}

Field measurements performed at Nha Trang beach show that under relatively constant offshore wave forcing (e.g., over a full tidal cycle), wave height at the base of the foreshore and swash motions 
were distinctly different between low and high tide as the swash zone oscillated between reflective (high Iribarren number) and dissipative (low Iribarren number; Figures 5 and 6) conditions. As a consequence of this tidal influence on the surf and swash hydrodynamics, the use of offshore wave characteristics solely is insufficient to predict $R_{S}([42,48,49]$ —see Figure 7). Present observations indicate that the lack of relationship between offshore wave characteristics and run-up is particularly evident during low tide conditions, when the LTT acts as a low-pass-filter and potentially enhances energy transfer to the infragravity band [45]. Some previous research has addressed this issue, suggesting that wave characteristics measured nearshore enable improved predictions of run-up [42]. The results presented here confirm this as using $H_{\text {SLIDAR }}$ in an Irribarren-type parameter resulted in better run-up estimation at Nha Trang than using offshore $H_{s}$. A similar tidal modulation has been observed on barred beaches (another type of intermediate beach) by [42,48]; however, in these cases, the spectral signature of the vertical run-up during low tide was composed of a mixture of both incident and infragravity components rather than dominated only by the infragravity band as observed at Nha Trang (Figure 5).

The beach slope is also seen to be a key factor that affects vertical run-up. This result is in line with the findings from $[42,50]$ who showed that including beach slope led to significant improvements in predictions of vertical run-up on a variety of intermediate beaches. At present, there is no consistent definition of the appropriate beach slope for use in run-up predictors; however, the laboratory experiments of [50] demonstrated that surf-zone slope led to better predictions than the active foreshore slope. The main reason for this result was thought to be that surf-zone slope is more physically related to the breaking conditions (position, height and type of breaking), which directly affects the swash dynamics. Recently, the authors of [47] demonstrated that the characteristics of the nearshore bathymetry, not usually accounted for in run-up predictors that use the offshore wave conditions and foreshore slope, is an important source of errors in run-up predictions, especially on barred beaches. Although the full surf-zone slope was not measured at Nha Trang, considering that this beach is a simple two-slope beach and that during the low tide conditions the Lidar was able to measure the LTT toe, it is possible that the foreshore slope observations were able to indirectly capture the tidally induced changes in the surf-zone slope.

In addition to the beach slope, the results presented here show that including significant wave height at the base of the foreshore improves the vertical run-up prediction. This result is in agreement with other studies, where a clear relationship between wave run-up and bore height and celerity at collapse was observed $[31,51]$. Although this improvement was verified for all the tidal stages (Table 1), it was more evident during low tide conditions when the most wave transformation takes place in the surf-zone leading to significant changes in the wave and run-up height. Considering the fact that the most extreme run-up excursions and potential coastal overtopping take place during high tide, our results suggest that offshore wave characteristics and foreshore slope can be used to predict extreme vertical run-up on intermediate beaches with an LTT.

\subsection{Upper-Beach Erosion and Recovery}

\subsubsection{Daily Evolution}

Observations of morphological evolution in the swash-zone, including daily and intratidal measurements presented in Sections 3.3 and 3.4, showed a continuous and rapid adjustment of the beach to different tidal and wave conditions. Overall, the morphological response of the swash-zone during the experiment can be divided into two main phases: (1) berm erosion; (2) berm formation. In both cases, the morphological response was likely to be the result of a morphological adjustment to changes in water levels and an offshore wave height. Higher water levels and larger waves exposed the initial berm to overtopping and consequent erosion, while milder waves and neap tides caused a neap berm to form $[52,53]$. Daily low tide surveys were sufficient to describe this overall beach response, but intra-tidal Lidar observations captured more detail of the morphodynamic processes on a sandy 
beach with an LTT. More specifically, the intra-tidal cycles of accretion and erosion observed in the mid swash-zone, during the individual tidal cycles between 27/11 and 01/12 (Figure 9). A similar morphological response has been observed on mixed coarse-grained beaches with a sandy LTT $[17,18]$ and on a pure gravel beach $[29,54]$ and associated with the cross-shore translation of the beach step. Despite some similarity, such as the location in the swash where these processes occur (mid swash), or the effect of the tide on lower foreshore wave height [29], important differences related with enhanced infiltration/exfiltration processes [17] and sediment transport mechanisms make a direct comparison with previous studies difficult. In addition to this, the mixed tide component observed at Nha Trang was not observed in any of the previous studies and may play an important role.

\subsubsection{Intra-Tidal Profile Evolution}

An accretion phase was observed between the falling tide and the peak of the first high tide. During this phase, the run-up was dominated by infragravity frequency motions and the swash slope was gradually decreasing (Figure 11). Infragravity swash events are characterized by a rapid uprush phase and potentially greater ability to transport sediments onto the foreshore. Slower, longer-lasting backwash flows on a gentler slope are expected to promote deposition conditions (sediments have more time to settle down, and the low angle reduces the downrush flows). In addition to this, and as it was observed on other sandy beaches $[55,56]$, the lower water table position during the lower tidal levels enhances uprush infiltration and contributes to the aggradation of the foreshore. This feedback between hydrodynamics and morphology led to the development of a sandy deposit in the mid-lower swash-zone during this period of time. This accretion phase lasted until the first high tide peak, and once the tide begins to rise again, the erosion phase is initiated (Figure 11).
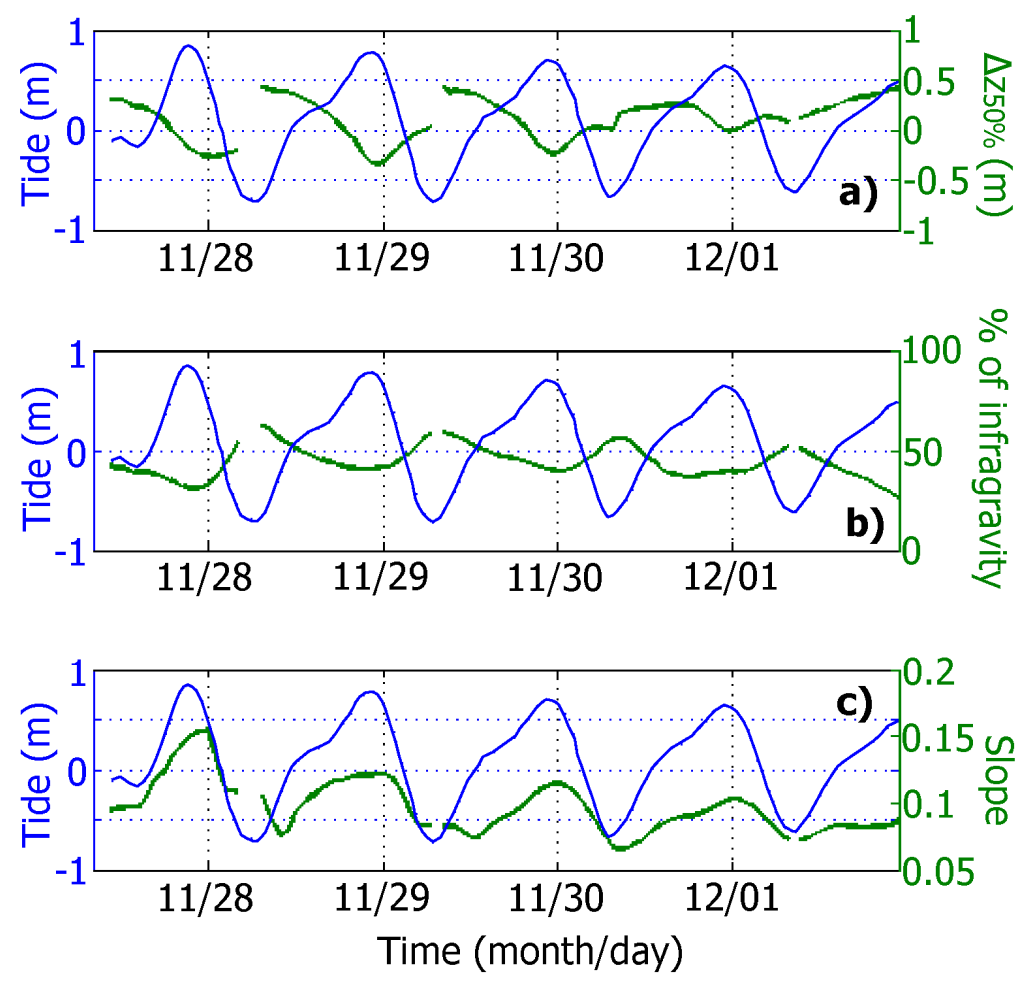

Figure 11. Cumulative vertical changes observed in the mid swash-zone $\left(\Delta_{\mathrm{z} 50 \%}\right)$ during the first four tidal cycles (a); percentage of infragravity on the vertical run-up observations (b); and slope changes (c).

An onshore migration of the surf and swash-zone gradually alters the hydrodynamic regime, and the run-up becomes gradually dominated by the incident band on the steepest sections of the beach. At this stage, plunging breakers and high turbulence rates are more likely to mobilize and suspend sediment into the water column around the break point [57]. The steeper swash-zone reduces 
the run-up asymmetry during this period of time, increasing the ability of the backwash to transport sediment offshore. As the tide rises, the swash-zone becomes steeper, reducing upslope transport and enhancing transport down the slope and erosion of the deposit. It is expected that at this time of the tide, the water table is higher in the foreshore, reducing uprush infiltration and enhancing downrush erosion [56]. This erosion phase stops at the beginning of the falling tide, when the average water level reaches its maximum on the steepest part of the beach. The falling tide is much faster than the rising phase, and few changes are observed in morphology. During gentle waves and neap tides, the swash zone slope becomes gentler (Figure 11c), favoring the conditions for deposition, and a new berm is formed. It is possible that at this stage, the morphology is approaching a new equilibrium with the dominant hydrodynamics and beach slope, resulting in limited morphological changes on the foreshore.

\section{Conclusions}

A nine-day field experiment was conducted on Nha Trang Beach (Vietnam), a microtidal sandy beach with a low tide terrace (LTT), to study swash hydrodynamics and morphodynamics under variable wave forcing. The tide was found to play a crucial role in controlling the hydrodynamics of the surf and swash zones. Lidar observations demonstrated that significant wave height measured just seaward of the swash zone together with the foreshore active slope improves predictions of vertical run-up. Under energetic waves and spring tide conditions, the upper-beach was eroded (berm erosion). When wave energy and tidal amplitude reduced, the beach rapidly recovered, and a new berm was built on a lower part of the foreshore. The Lidar dataset has provided new insights on intra-tidal morphological changes in the mid swash-zone, with individual tidal cycles showing distinct phases of accretion and erosion. Using multiple linear regression analysis, it was possible to verify that the key factors underlying the mid swash cycles of accretion/erosion are the foreshore slope and infragravity swash motions.

Author Contributions: Conceptualization, R.A. and L.P.A. and C.B.; methodology, R.A., L.P.A., C.B., and P.G.d.S.; software, L.P.A.; validation, L.P.A.; formal analysis, L.P.A., R.A., C.B., E.B., P.G.d.S.; investigation, L.P.A., P.M., R.A., R.B., C.B., N.S., E.B., F.F., C.C., J.A., M.B., P.G., N.T.V., D.H.T., P.G.d.S.; data curation, L.P.A.; writing-original draft preparation, L.P.A.; writing-review and editing, L.P.A., P.M., R.A., R.B., C.B., N.S., E.B., F.F., C.C., J.A., M.B., P.G., N.T.V., D.H.T., P.G.d.S.; visualization, L.P.A., P.M., R.A., R.B., C.B., N.S., E.B., F.F., C.C., J.A., M.B., P.G., N.T.V., D.H.T., P.G.d.S.; supervision, R.A.; project administration, R.A. and N.T.V.; funding acquisition, R.A. and N.T.V. All authors have read and agreed to the published version of the manuscript.

Funding: This research was funded by Agence Nationale de la Recherché (ANR, France), grant number ANR-14-ASTR-0019 and the APC was funded by first author voucher.

Acknowledgments: This work received financial support from Vietnamese (MOST2/216/QD/BKHCN-No2994) and French grant through the COASTVAR project (ANR-14-ASTR-0019). D.H.T PhD was funded by the ARTS-IRD program. The authors of this work would like to thank the support provided by all the participants present in this field experiment. The authors would like to thank the valuable contribution from the two reviewers that provided very useful suggestions to improve this manuscript.

Conflicts of Interest: The authors declare no conflict of interest.

\section{References}

1. Schepper, R.; De Vries, S.; Reniers, A.; Katsman, C.; Almar, R.; Bergsma, E.; Davidson, M. Multi-timescale shoreline modelling. Coast. Sediments 2019, 2200-2210. [CrossRef]

2. Raubenheimer, B.; Guza, R. Observations and predictions of run-up. J. Geophys. Res. Ocean. 1996, 101, 25575-25587. [CrossRef]

3. Ruggiero, P.; Holman, R.A.; Beach, R. Wave run-up on a high-energy dissipative beach. J. Geophys. Res. Ocean. 2004, 109. [CrossRef]

4. Wright, L.; Short, A.D. Morphodynamic variability of surf zones and beaches: A synthesis. Mar. Geol. 1984, 56, 93-118. [CrossRef]

5. Miles, J.; Russell, P. Dynamics of a reflective beach with a low tide terrace. Cont. Shelf Res. 2004, 24, 1219-1247. [CrossRef] 
6. Almar, R.; Almeida, P.; Blenkinsopp, C.; Catalán, P. Surf-swash interactions on a low-tide terraced beach. J. Coast. Res. 2016, 75, 348-352. [CrossRef]

7. Aagaard, T.; Greenwood, B.; Hughes, M. Sediment transport on dissipative, intermediate and reflective beaches. Earth Sci. Rev. 2013, 124, 32-50. [CrossRef]

8. Aagaard, T.; Hughes, M.G. Breaker turbulence and sediment suspension in the surf zone. Mar. Geol. 2010, 271, 250-259. [CrossRef]

9. Puleo, J.; Beach, R.; Holman, R.A.; Allen, J. Swash zone sediment suspension and transport and the importance of bore-generated turbulence. J. Geophys. Res. Ocean. 2000, 105, 17021-17044. [CrossRef]

10. Petti, M.; Longo, S. Turbulence experiments in the swash zone. Coast. Eng. 2001, 43, 1-24. [CrossRef]

11. Shen, M.; Meyer, R. Climb of a bore on a beach Part 3. Run-up. J. Fluid Mech. 1963, 16, 113-125. [CrossRef]

12. Hughes, M.G.; Moseley, A.S. Hydrokinematic regions within the swash zone. Cont. Shelf Res. 2007, 27, 2000-2013. [CrossRef]

13. Power, H.; Holman, R.; Baldock, T. Swash zone boundary conditions derived from optical remote sensing of swash zone flow patterns. J. Geophys. Res. Ocean. 2011, 116. [CrossRef]

14. Almar, R.; Blenkinsopp, C.; Almeida, L.; Cienfuegos, R.; Catalán, P. A new remote predictor of wave reflection based on run-up asymmetry. Estuar. Coast. Shelf Sci. 2018, 217, 1-8. [CrossRef]

15. Masselink, G.; Puleo, J.A. Swash-zone morphodynamics. Cont. Shelf Res. 2006, 26, 661-680. [CrossRef]

16. Hardisty, J.; Collier, J.; Hamilton, D. A calibration of the Bagnold beach equation. Mar. Geol. 1984, 61, 95-101. [CrossRef]

17. Kulkarni, C.D.; Levoy, F.; Monfort, O.; Miles, J. Morphological variations of a mixed sediment beachface (Teignmouth, UK). Cont. Shelf Res. 2004, 24, 1203-1218. [CrossRef]

18. Strahler, A.N. Tidal cycle of changes in an equilibrium beach, Sandy Hook, New Jersey. J. Geol. 1966, 74, 247-268. [CrossRef]

19. Austin, M.J.; Buscombe, D. Morphological change and sediment dynamics of the beach step on a macrotidal gravel beach. Mar. Geol. 2008, 249, 167-183. [CrossRef]

20. Masselink, G.; Li, L. The role of swash infiltration in determining the beachface gradient: A numerical study. Mar. Geol. 2001, 176, 139-156. [CrossRef]

21. Turner, I.L.; Russell, P.E.; Butt, T. Measurement of wave-by-wave bed-levels in the swash zone. Coast. Eng. 2008, 55, 1237-1242. [CrossRef]

22. Ibaceta, R.; Almar, R.; Lefebvre, J.P.; Mensah-Senoo, T.; Layrea, W.S. High frequency monitoring of swash hydro-morphodynamics on a reflective beach (Grand Popo, Benin): A new method. In Proceedings of the 34th Conference on Coastal Engineering, Seoul, Korea, 15-20 June 2014.

23. Ibaceta, R.; Almar, R.; Catalán, P.A.; Blenkinsopp, C.E.; Almeida, L.P.; Cienfuegos, R. Assessing the Performance of a Low-Cost Method for Video-Monitoring the Water Surface and Bed Level in the Swash Zone of Natural Beaches. Remote Sens. 2018, 10, 49. [CrossRef]

24. Brodie, K.L.; Raubenheimer, B.; Elgar, S.; Slocum, R.K.; McNinch, J.E. Lidar and pressure measurements of inner-surfzone waves and setup. J. Atmos. Ocean. Technol. 2015, 32, 1945-1959. [CrossRef]

25. Martins, K.; Blenkinsopp, C.E.; Zang, J. Monitoring individual wave characteristics in the inner surf with a 2-dimensional laser scanner (Lidar). J. Sens. 2016, 2016, 7965431. [CrossRef]

26. Martins, K.; Blenkinsopp, C.E.; Power, H.E.; Bruder, B.; Puleo, J.A.; Bergsma, E.W.J. High-resolution monitoring of wave transformation in the surf zone using a Lidar scanner array. Coast. Eng. 2017, 128, 37-43. [CrossRef]

27. Blenkinsopp, C.; Mole, M.; Turner, I.; Peirson, W. Measurements of the time-varying free-surface profile across the swash zone obtained using an industrial LIDAR. Coast. Eng. 2010, 57, 1059-1065. [CrossRef]

28. Vousdoukas, M.; Kirupakaramoorthy, T.; Oumeraci, H.; De La Torre, M.; Wübbold, F.; Wagner, B.; Schimmels, S. The role of combined laser scanning and video techniques in monitoring wave-by-wave swash zone processes. Coast. Eng. 2014, 83, 150-165. [CrossRef]

29. Almeida, L.; Masselink, G.; Russell, P.; Davidson, M. Observations of gravel beach dynamics during high energy wave conditions using a laser scanner. Geomorphology 2015, 228, 15-27. [CrossRef]

30. Martins, K.; Blenkinsopp, C.E.; Deigaard, R.; Power, H.E. Energy Dissipation in the Inner Surf Zone: New Insights from Lidar-Based Roller Geometry Measurements. J. Geophys. Res. Ocean. 2018, 123, 3386-3407. [CrossRef] 
31. Bergsma, E.W.J.; Blenkinsopp, C.E.; Martins, K.; Almar, R.; de Almeida, L.P.M. Bore collapse and wave run-up on a sandy beach. Cont. Shelf Res. 2019, 174, 132-139. [CrossRef]

32. O'Dea, A.; Brodie, K.L.; Hartzell, P. Continuous Coastal Monitoring with an Automated Terrestrial Lidar Scanner. J. Mar. Sci. Eng. 2019, 7, 37. [CrossRef]

33. Almar, R.; Blenkinsopp, C.; Almeida, L.P.; Bergsma, E.W.; Catalan, P.A.; Cienfuegos, R.; Viet, N.T. Complex intertidal beach profile estimation from reflected wave measurements. Coast. Eng. 2019, 151, 58-63. [CrossRef]

34. Almar, R.; Marchesiello, P.; Almeida, L.P.; Thuan, D.H.; Tanaka, H.; Viet, N.T. Shoreline Response to a Sequence of Typhoon and Monsoon Events. Water 2017, 9, 364. [CrossRef]

35. Lefebvre, J.P.; Almar, R.; Viet, N.T.; Thuan, D.H.; Binh, L.T.; Ibaceta, R.; Duc, N.V. Contribution of swash processes generated by low energy wind waves in the recovery of a beach impacted by extreme events: Nha Trang, Vietnam. J. Coast. Res. 2014, 70, 663-668. [CrossRef]

36. Mau, L.D. Overview of Natural Geographical Conditions of Nha Trang Bay; Technical Report; Nha Trang Institute of Oceanography: Nha Trang, Vietnam, 2014.

37. Almeida, L.; Almar, R.; Meyssignac, B.; Viet, N. Contributions to Coastal Flooding Events in Southeast of Vietnam and their link with Global Mean Sea Level Rise. Geosciences 2018, 8, 437. [CrossRef]

38. Thuan, D.H.; Binh, L.T.; Viet, N.T.; Hanh, D.K.; Almar, R.; Marchesiello, P. Typhoon impact and recovery from continuous video monitoring: A case study from Nha Trang Beach, Vietnam. J. Coast. Res. 2016, 75, $263-267$. [CrossRef]

39. Hanh, P.T.T.; Furukawa, M. Impact of sea level rise on coastal zone of Vietnam. Bull. Coll. Sci. Univ. 2007, 84,45 .

40. Andriolo, U.; Almeida, L.P.; Almar, R. Coupling terrestrial Lidar and video imagery to perform 3D intertidal beach topography. Coast. Eng. 2018, 140, 232-239. [CrossRef]

41. Battjes, J.A. Surf similarity. In Proceedings of the 14th International Conference on Coastal Engineering, Copenhagen, Denmark, 24-28 June 1974.

42. Brodie, K.L.; Slocum, R.K.; McNinch, J.E. New insights into the physical drivers of wave run-up from a continuously operating terrestrial laser scanner. In Proceedings of the 2012 Oceans-IEEE, Hampton Roads, VA, USA, 14-19 October 2012.

43. Waddell, E. Dynamics of Swash and Implication to Beach Response; Technical Report; Louisiana State University, Coastal Studies Institute: Baton Rouge, LA, USA, 1973.

44. Stockdon, H.F.; Holman, R.A.; Howd, P.A.; Sallenger, A.H. Empirical parameterization of setup, swash, and run-up. Coast. Eng. 2006, 53, 573-588. [CrossRef]

45. Hunt, I.A. Design of sea walls and bkeakwaters. J. Waterw. Ports Ocean Eng. 1959, 85, 123-152.

46. Holman, R.A. Extreme value statistics for wave run-up on a natural beach. Coast. Eng. 1986, 9, 527-544. [CrossRef]

47. Gomes da Silva, P.; Medina, R.; González, M.; Garnier, R. Wave reflection and saturation on natural beaches: The role of the morphodynamic beach state in incident swash. Coast. Eng. 2019, 153, 103540. [CrossRef]

48. Guedes, R.M.C.; Bryan, K.R.; Coco, G.; Holman, R. The effects of tides on swash statistics on an intermediate beach. J. Geophys. Res. Ocean. 2011, 116. [CrossRef]

49. Gomes da Silva, P.; Coco, G.; Garnier, R.; Klein, A.H.F. On the prediction of run-up, setup and swash on beaches. Earth Sci. Rev. 2020, 204, 103148. [CrossRef]

50. Khoury, A.; Jarno, A.; Marin, F. Experimental study of run-up for sandy beaches under waves and tide. Coast. Eng. 2019, 144, 33-46. [CrossRef]

51. Blenkinsopp, C.E.; Matias, A.; Howe, D.; Castelle, B.; Marieu, V.; Turner, I.L. Wave runup and overwash on a prototype-scale sand barrier. Coast. Eng. 2016, 113, 88-103. [CrossRef]

52. Hine, A.C. Mechanisms of berm development and resulting beach growth along a barrier spit complex. Sedimentology 1979, 26, 333-351. [CrossRef]

53. Weir, F.M.; Hughes, M.G.; Baldock, T.E. Beach face and berm morphodynamics fronting a coastal lagoon. Geomorphology 2006, 82, 331-346. [CrossRef]

54. Poate, T.; Masselink, G.; Davidson, M.; McCall, R.; Russell, P.; Turner, I. High frequency in-situ field measurements of morphological response on a fine gravel beach during energetic wave conditions. Mar. Geol. 2013, 342, 1-13. [CrossRef]

55. Grant, U.S. Influence of the water table on beach aggradation and degradation. J. Mar. Res. 1948, 7, 655-660. 
56. Duncan, J.R. The effects of water table and tide cycle on swash-backwash sediment distribution and beach profile development. Mar. Geol. 1964, 2, 186-197. [CrossRef]

57. Brocchini, M.; Baldock, T. Recent advances in modeling swash zone dynamics: Influence of surf-swash interaction on nearshore hydrodynamics and morphodynamics. Rev. Geophys. 2008, 46. [CrossRef]

(C) 2020 by the authors. Licensee MDPI, Basel, Switzerland. This article is an open access article distributed under the terms and conditions of the Creative Commons Attribution (CC BY) license (http://creativecommons.org/licenses/by/4.0/). 